\begin{tabular}{|c|c|c|c|c|}
\hline JURNAL & VOLUME 1 & NOMOR 1 & HALAMAN 1-70 & $\begin{array}{c}\text { ISSN 2655-8823 }(p) \\
\text { ISSN - }(e)\end{array}$ \\
KOLABORASI RESOLUSI KONFLIK & HOR \\
\hline
\end{tabular}

\title{
RESOLUSI KONFLIK AGRARIA DI DESA GENTENG KECAMATAN SUKASARI KABUPATEN SUMEDANG
}

\author{
Wandi Adiansah, \\ Mahasiswa Program Magister Pascasarjana Kesejahteraan Sosial FISIP UNPAD \\ Peneliti di Pusat Studi Konflik dan Resolusi Konflik FISIP UNPAD \\ E-mail: adiansahw@gmail.com \\ Nurliana Cipta Apsari dan Santoso Tri Raharjo \\ Dosen Program Pascasarjana Kesejahteraan Sosial FISIP UNPAD \\ E-mail:nurliana.cipta.apsari@unpad.ac.id, santoso.tri.raharjo@unpad.ac.id
}

\begin{abstract}
ABSTRAK
Konflik adalah fenomena yang tidak dapat dihindarkan dalam masyarakat. Salah satu konflik yang terjadi di masyarakat yaitu konfik agraria di Desa Genteng Kecamatan Sukasari Kabupaten Sumedang. Konflik ini terjadi karena adanya perbedaan kepentingan dalam penggunaan lahan antara masyarakat lokal dengan Perum Perhutani. Dalam konflik agraria ini, berbagai pihak berupaya untuk melakukan resolusi konflik agar konflik yang terjadi tidak terus berlanjut.

Penelitian ini menggunakan metode kualitatif dengan teknik pengumpulan data berupa studi literatur. Data yang terkumpul kemudian diolah dengan tahapan reduksi data, analisis data dan penarikan kesimpulan. Hasil dari penelitian ini yaitu upaya resolusi konflik agraria di Desa Genteng Kecamatan Sukasari Kabupaten Sumedang dilakukan yaitu dengan dibentuknya konsensus baru di masyarakat dengan diperbolehkannya para petani untuk melakukan aktivitas pertanian di lahan kehutanan namun dengan jenis tanaman tertentu yaitu tanaman kopi.
\end{abstract}

Kata kunci: konflik agraria, resolusi konflik.

\begin{abstract}
ABSTRACK
Conflict is a phenomenon that cannot be avoided in society. One of the conflicts that occurred in the community was the agrarian conflict in the Genteng Village, Sukasari District, Sumedang District. This conflict occurred because of differences in interests in land use between local communities and Perum Perhutani. In this agrarian conflict, various parties are trying to make conflict resolution so that the conflict does not continue.

This study uses qualitative methods with data collection techniques in the form of literature studies. The collected data is then processed by stages of data reduction, data analysis and conclusion. The results of this study are efforts to resolve agrarian conflict in the Genteng Village, Sukasari Sub-District, Sumedang District, namely by establishing a new consensus in the community by allowing farmers to carry out agricultural activities on forest land but with certain types of plants.
\end{abstract}

Keywords: agrarian conflict, conflict resolution.

\section{PENDAHULUAN}

Konflik merupakan fenomena yang selalu melekat dalam kehidupan masyarakat, sebagai realitas yang tidak dapat dihindarkan dan akan selalu dan terus terjadi (Nasikun dalam Nulhaqim, 2017:76). Konflik ini terjadi baik pada tataran individu maupun tataran kelompok dalam masyarakat (Putra, 2014). Menurut Pasal 1 butir 1 UU No. 7 Tahun 2012 tentang Penanganan Konflik Sosial, dijelaskan bahwa yang dimaksud dengan konflik sosial yaitu perseteruan dan/atau benturan fisik dengan kekerasan antara dua kelompok masyarakat atau lebih yang berlangsung dalam waktu tertentu dan berdampak luas yang mengakibatkan ketidaknyamanan dan disintegrasi sosial sehingga mengganggu stabilitas nasional dan menghambat pembangunan nasional.

Menurut De Dreu dan Gelfand (2007) dalam Putra (2013:1) konflik merupakan proses yang mulai ketika individu atau kelompok mempersepsi terjadinya 


\begin{tabular}{|c|c|c|c|c|}
\hline $\begin{array}{c}\text { JURNAL } \\
\text { KOLABORASI RESOLUSI KONFLIK }\end{array}$ & VOLUME 1 & NOMOR 1 & HALAMAN 1-70 & $\begin{array}{c}\text { ISSN 2655-8823 }(p) \\
\text { ISSN - }(e)\end{array}$ \\
\hline
\end{tabular}

perbedaan atau oposisi antara dirinya dengan individu atau kelompok lain mengenai minat dan sumber daya, keyakinan, nilai, atau praktik-praktik lainnya. Mengacu pada Ritzer dan Douglas (2010) mengenai teori konflik Dahrendrof melihat masyarakat setiap saat tunduk pada proses perubahan, pertikaian dan konflik dalam sistem sosial serta melihat berbagai elemen kemasyarakatan menyumbang terhadap disintegrasi dan perubahan. Keteraturan yang terdapat dalam masyarakat berasal dari pemaksaan terhadap anggotanya oleh mereka yang berada diatas dengan menekankan pada peran kekuasaan dalam mempertahankan ketertiban dalam masyarakat. Berdasarkan teori ini dapat dipahami bahwa masyarakat terbentuk dengan adanya konsensus dan konflik menjadi persyaratan satu sama lain.

Berdasarkan beberapa konsep mengenai konflik dimuka, maka dapat disimpulkan bahwa konflik sosial adalah suatu situasi proses yaitu proses interaksi antara dua atau lebih individu atau kelompok dalam memperebutkan objek yang sama demi kepentingannya. Salah satu bentuk konflik yang terjadi dalam masyarakat yaitu konflik agraria. Konflik agraria sendiri merupakan salah satu bentuk konflik yang berkaitan dengan tanah. Pada dasarnya tanah adalah aset yang paling penting dalam kehidupan masyarakat karena tanah adalah sumber kehidupan. Dalam negara agraris tanah merupakan sumber utama dalam berproduksi sehingga di Indonesia dalam hak kepemilikan, hak guna usaha, hak pakai, hak sewa, hak membuka tanah, hak memungut hasil hutan dibatasi dalam Undang-Undang Pokok Agraria. Permasalahan mengenai pertanahan bisa menimbulkan konflik yang berkepanjangan antara orang dengan orang maupun orang dengan badan hukum.

Berdasarkan catatan Konsorsium Pembaruan Agraria (KPA) Tahun 2017 dalam kurun waktu 2017, KPA mencatat sedikitnya telah terjadi 659 kejadian konflik agraria di berbagai wilayah di Indonesia dengan luasan 520.491,87 hektar. Konflik-konflik tersebut melibatkan sedikitnya 652.738 Kepala Keluarga (KK). Dibanding tahun 2016, angka kejadian konflik pada tahun ini menunjukkan kenaikan yang sangat siginifikan di mana terjadi peningkatan hingga $50 \%$. Jika dirata-rata, hampir dua konflik agraria terjadi dalam satu hari di Indonesia sepanjang tahun 2017.

KPA (2017) juga mencatat konflik Agraria ini terjadi dalam beberapa sektor mulai dari sektor perkebunan, properti, infrastruktur, pertanian, kehutanan, pesisir/kelautan dan pertambangan. Provinsi Jawa Timur, Sumatera Utara, Jawa Barat, Riau dan Lampung adalah lima provinsi utama tempat konflik agraria paling banyak sepanjang 2017. Secara berurutan, lima besar provinsi dimana kejadian konflik agraria adalah: Jawa Timur dengan 60 (9,10\%). Kemudian, Sumatera Utara dengan 59 konflik agraria $(8,95 \%)$, Jawa Barat dengan 55 konflik agraria $(8,34 \%)$, Riau dengan 47 konflik agraria $(7,13 \%)$, dan terakhir Lampung dengan 35 konflik agraria (5,3\%). Secara khusus, Provinsi Jawa Timur, Jawa Barat, dan Sumatera Utara konflik agraria di wilayah ini banyak disumbang oleh Perkebunan Negara (PTPN) dan Perhutani.

Menurut Zakie (2016) konflik agraria muncul karena kebutuhan manusia akan tanah selalu bertambah seiring dengan pertambahan penduduk. Hal tersebut melahirkan paradigma bahwa kebutuhan akan tanah pertanian bagi petani pada saat ini sangatlah mendesak. Sementara banyak tanah terlantar yang tidak digarap adalah sebuah keniscayaan bagi petani yang tidak mempunyai tanah garapan terutama pada tanah-tanah yang dikuasai oleh Perum Perhutani. Petani lokal yang berdomisili di tepian hutan, memandang bahwa secara tradisional tanah yang ada di kawasan itu merupakan sumber penghidupan, cadangan perluasan tanah garapan, dan sekaligus sebagai daerah food security (Permadi, 2016:226).

Bagi penduduk lokal, gangguan ekologi yang datang dari luar hutan akan 


\begin{tabular}{|c|c|c|c|c|}
\hline JURNAL & VOLUME 1 & NOMOR 1 & HALAMAN 1-70 & $\begin{array}{c}\text { ISSN 2655-8823 }(p) \\
\text { ISSN - }(e)\end{array}$ \\
\hline
\end{tabular}

mengancam kehidupan sosial dan ekonomi mereka. Sementara perusahaan pemegang hak penguasaan hutan memandang bahwa kawasan hutan merupakan tanah yang secara legal telah dikuasakan negara kepadanya untuk dikelola secara komersial dengan tujuan mendapatkan keuntungan yang sebesar-besarnya. Persoalan sosial inilah yang menyebabkan konflik yang jika tidak ditangani dengan baik dapat mengancam harmonisasi sosial (Rokhmad, 2016).

Otoritas penguasaan dan pengelolaan sumber daya hutan diberikan kepada Perum Perhutani berdasarkan Undang-undang No. 41 Tahun 1999 tentang Kehutanan (selanjutnya disebut UU Kehutanan), dimana Perum Perhutani merupakan Badan Usaha Milik Negara (BUMN) yang berada di bawah Kementerian Lingkungan Hidup dan Kehutanan. Hak yang dimiliki Perum Perhutani atas sumber daya hutan adalah hak pengelolaan yang berasal dari hak menguasai negara melalui tiga peran pokok, yaitu sebagai penguasa tanah hutan, perusahaan kehutanan (forest enterprise) dan institusi konservasi hutan (forest conservation institution). Konsekuensi yuridis yang muncul adalah petani yang menggarap tanah kehutanan (termasuk memanfaatkan hasil hutan) seringkali menimbulkan konflik tanah kawasan hutan di beberapa daerah.

Salah satu konflik agraria antara petani dan Perum Perhutani yang pernah terjadi yaitu kasus konflik agraria di Desa Genteng, Kecamatan Sukasari, Kabupaten Sumedang. Mayoritas mata pencaharian masyarakat Desa Genteng adalah bertani. Layaknya seorang petani, untuk meningkatkan perekonomiannya maka mereka membutuhkan tanah untuk melakukan aktivitas pertaniannya. Bagi petani yang tidak memiliki lahan pertanian pribadi, mereka memanfaatkan tanah terlantar milik Perum Perhutani yang ada di kawasan hutan di sekitar tempat tinggal mereka untuk bercocok tanam. Konflik agraria ini muncul ketika Perum Perhutani berusaha mengambil alih lahan yang sedang digarap oleh petani dengan tujuan untuk melakukan konservasi hutan sebagai upaya untuk menjaga ekosistem dan kelestarian hutan. Petani yang juga merasa memiliki hak untuk menggunakan lahan tersebut merasa dirugikan. Perbedaan kepentingan inilah yang akhirnya menyebabkan konflik agraria di Desa Genteng. Hal ini menegaskan pernyataan Chandra (1992:20) bahwa konflik dapat terjadi akibat adanya perbedaan kepentingan diantara komunitas masyarakat.

Bagi masyarakat petani Desa Genteng jaminan atas tanah tertuang dalam UndangUndang No. 5 Tahun 1960 tentang PokokPokok Agraria (selanjutnya disebut UU Pokok Agraria). Undang-undang ini dibuat untuk mengatur mengenai hak-hak pertanahan bagi masyarakat Indonesia secara menyeluruh. Di lain pihak UU Kehutanan merupakan salah bentuk jaminan bagi Perhutani untuk melakukan konservasi hutan. Hal ini membuat banyak petani Desa Genteng tergusur dari tanah yang sedang dia kelola untuk menyambung hidup.

Pada dasarnya konflik tidak dapat dibiarkan dan harus dikelola dengan baik karena jika tidak, yang terjadi adalah kerugian bagi kehidupan masyarakat. Konflik sering kali dianggap sebagai masalah sosial yang sulit untuk diselesaikan. Dalam upaya penanganan konflik diperlukan pemahaman dan metode yang komprehensif. Pemahaman yang komprehensif ini merujuk pada pemahaman konflik yang tidak saja dilihat dari peristiwa konflik yang terjadi, akan tetapi juga melihat akar masalah konflik dan sistem sosial yang ada di masyarakat. Hal ini diperlukan untuk mencegah munculnya pola-pola penanganan konflik yang justru akan mengaburkan pokok permasalahan dari konflik yang terjadi.

Berdasarkan hal tersebut maka konflik yang terjadi pada masyarakat harus dapat dimanajemen secara baik, hal ini dikenal dengan istilah manaemen konflik. Menurut Fuad \& Maskanah (2000) manajemen 


\begin{tabular}{|c|c|c|c|c|}
\hline JURNAL & VOLUME 1 & NOMOR 1 & HALAMAN 1-70 & $\begin{array}{c}\text { ISSN 2655-8823 }(p) \\
\text { ISSN - }(e)\end{array}$ \\
\hline
\end{tabular}

konflik merupakan langkah-langkah yang diambil para pelaku atau pihak ketiga dalam rangka mengarahkan perselisihan ke arah hasil tertentu yang mungkin atau tidak mungkin menghasilkan suatu akhir berupa penyelesaian konflik dan mungkin atau tidak mungkin menghasilkan ketenangan, hal positif, kreatif, bermufakat atau agresif. Manajemen konflik dapat melibatkan bantuan diri sendiri, kerjasama dalam memecahkan masalah (dengan atau tanpa bantuan pihak ketiga) atau pengambilan keputusan oleh pihak ketiga. Suatu pendekatan yang berorientasi pada proses manajemen konflik menunjuk pada pola komunikasi (termasuk perilaku) para pelaku dan bagaimana regulasi yang ada dapat mengatur kepentingan para pihak (Harun dan Dwiprabowo, 2014:265-280).

Manajemen konflik pada dasarnya dapat dilakukan melalui pendekatan resolusi konflik. Resolusi konflik menurut Weitzman \& Weitzman (dalam Morton \& Coleman 2000: 197) mendefinisikan resolusi konflik sebagai sebuah tindakan pemecahan masalah bersama (solve $a$ problem together). Lain halnya dengan Fisher et al (2001:7) yang menjelaskan bahwa resolusi konflik adalah usaha menangani sebab-sebab konflik dan berusaha membangun hubungan baru yang bisa tahan lama diantara kelompokkelompok yang berseteru. Pada akhirnya setiap resolusi konflik harus mampu mendorong para pihak yang berkonflik untuk menghentikan semua tindakan perselisihan terhadap satu sama lain dan dapat saling menerima keberadaan satu sama lain (Wallensteen, 2002:8).

Resolusi konflik dapat dilakukan dengan menggunakan berbagai pendekatan. Salah satu pendekatan dalam penanganan konflik yaitu pendekatan berbasis komunitas. Menurut Haider (2009) pendekatan berbasis masyarakat/komunitas (Community Based Approach) dalam resolusi konflik yaitu suatu pendekatan yang berusaha memberdayakan kelompok dan lembaga yang berada pada level komunitas lokal dengan memberikan kontrol langsung kepada masyarakat atas pengambilan keputusan, perencanaan langkah aksi, pelaksanaan serta pemantauan, melalui proses yang menekankan partisipasi dan manajemen inklusif dari masyarakat lokal. Bentuk pendekatan resolusi konflik berbasis komunitas menurut Haider (2009) terdapat lima bentuk utama yaitu mengoptimalkan peran pemerintah lokal, melakukan upaya pemberdayaan komunitas lokal, melakukan upaya pemenuhan kebutuhan masyarakat, mengoptimalkan pemanfaatan modal sosial dan melakukan upaya kontrak sosial.

Terkait dengan konflik agraria tersebut, pada dasarnya apabila konflik dibiarkan dan tidak dikelola dengan seksama, maka yang terjadi adalah kerugian bagi kehidupan masyarakat, karena akan menimbulkan banyak korban baik harta atau nyawa serta tata kehidupan sosial yang tidak aman dan tidak sehat. Berbagai upaya dilakukan untuk mengatasi konflik antara masyarakat Desa Genteng dengan Perhutani ini. Dalam tulisan ini, akan dikaji lebih lanjut bagaimana pendekatan resolusi konflik yang diterapkan dalam mengatasi konflik agraria di Desa Genteng Kecamatan Sukasari Kabupaten Sumedang.

\section{METODE PENELITIAN}

Metode penelitian dalam kajian ini yaitu menggunakan metode penelitian kualitatif deskriptif dengan tujuan untuk menganalisis resolusi konflik berbasis komunitas berdasarkan perspektif Human Behaviour and Sosial Enviromnent dan perspektif pekerjaan sosial mikro. Data dalam artikel ini diperoleh melalui teknik studi literatur dan studi penelitian terdahulu. Data tersebut kemudian diolah melalui tahapan reduksi data, analisis hingga penarikan kesimpulan.

\section{HASIL DAN ANALISIS \\ Gambaran Umum Desa Genteng}

Desa Genteng merupakan salah satu desa yang terletak di Kecamatan Sukasari 


\begin{tabular}{|c|c|c|c|c|}
\hline $\begin{array}{c}\text { JURNAL } \\
\text { KOLABORASI RESOLUSI KONFLIK }\end{array}$ & VOLUME 1 & NOMOR 1 & HALAMAN 1-70 & $\begin{array}{c}\text { ISSN 2655-8823 }(p) \\
\text { ISSN - }(e)\end{array}$ \\
\hline
\end{tabular}

Kabupaten Sumedang. Sebelah utara dan barat desa ini berbatasan langsung dengan Gunung Manglayang. Oleh karena itu, topografi desa ini sebagian besar merupakan daerah pegunungan dan perbukitan yang termasuk dalam kategori dataran tinggi dengan ketinggian tempat 800-1200 mdpl. Berdasarkan data dari Profil Desa Genteng Tahun 2017, desa ini terbagi kedalam 6 dusun, 19 RW dan 76 RT dan dihuni oleh 6.139 jiwa penduduk dengan 2.219 Kepala Keluarga.

Mayoritas penduduk Desa Genteng menggantungkan hidup dari sektor pertanian, perkebunan dan peternakan. Selain sumber daya alam yang sangat mendukung dalam sektor tersebut, masyarakat Desa Genteng juga memiliki keterampilan dalam pengelolaan sumber daya alam berupa bertani sayuran organik, padi, palawija, tembakau, dan keterampilan berternak. Pada tahun 2017 tercatatat terdapat 2.856 orang petani dan 1.332 orang peternak.

\section{Asal Mula Konflik Agraria Desa Genteng}

Mata pencaharian penduduk Desa Genteng yang sebagian besar merupakan petani menuntut adanya ketersediaan lahan pertanian untuk bercocok tanam. Bagi petani yang tidak memiliki lahan pertanian pribadi, mereka memanfaatkan tanah terlantar milik Perum Perhutani yang ada di kawasan hutan Gunung Manglayang di sekitar tempat tinggal mereka untuk bercocok tanam. Jenis tanaman yang ditanam oleh petani Desa Genteng di kawasan hutan tersebut yaitu sayuran, palawija dan tembakau. Aktivitas pertanian di kawasan hutan ini telah dilakukan selama belasan tahun. Setiap tahunnya petani berusaha untuk melakukan pembukaan lahan di kawasan hutan tersebut.

Berdasarkan sejarah kebijakan pertanahan di Indonesia periode 2005-saat ini, kebijakan pertanahan diarahkan pada "tanah untuk keadilan dan kesejahteraan rakyat". Periode ini ditandai dengan kebijakan penertiban tanah terlantar, penyelesaian sengketa, redistribusi tanah, peningkatan legalisasi aset-tanah masyarakat yang diimplementasikan melalui Reforma Agraria (Firmansyah, dkk, 2018). Pada periode ini, tanah-tanah terlantar terutama yang berada di kawasan hutan ditertibkan dan diambil alih oleh Perum Perhutani. Begitu pun tanah terlantar yang ada di kawasan hutan Desa Genteng. Konflik agraria Desa Genteng ini pun muncul ketika Perum Perhutani berusaha mengambil alih lahan yang sedang digarap oleh petani dengan tujuan untuk melakukan konservasi hutan sebagai upaya untuk menjaga ekosistem dan kelestarian hutan. Petani yang juga merasa memiliki hak untuk menggunakan lahan tersebut merasa dirugikan. Perbedaan kepentingan inilah yang akhirnya menyebabkan konflik agraria di Desa Genteng.

\section{Analisis Resolusi Konflik Agraria Desa Genteng}

Konflik agraria yang terjadi di Desa Genteng Kecamatan Sukasari Kabupaten Sumedang antara masyarakat petani dengan Perum Perhutani tersebut pada dasarnya tidak terlepas dari multiple system yang dikemukakan oleh Zastrow. Zastrow (2007) menjelaskan bahwa setiap individu secara konstan dan dinamis terlibat interaksi dengan lingkungan sosial mereka baik dalam sistem mikro, mezzo maupun makro (multiple system). Sistem mikro mengacu pada seorang individu yang dalam istilah Zastrow terbagi menjadi tiga sistem utama yaitu sistem biologis, psikologis, dan sosial (biopsikososial). Dalam sistem mikro ini Zastrow berfokus pada kebutuhan, masalah, dan kekuatan individu. Sistem kedua yaitu sistem mezzo yang mengacu pada kelompok kecil termasuk keluarga, kelompok kerja, dan kelompok sosial lainnya. Ketiga yaitu sistem makro yang mengacu pada sistem yang lebih besar. Dalam sistem makro Zastrow berfokus pada kondisi sosial, politik, dan ekonomi serta kebijakan yang mempengaruhi akses masyarakat terhadap sumber daya dan kualitas hidup mereka. 


\begin{tabular}{|c|c|c|c|c|}
\hline $\begin{array}{c}\text { JURNAL } \\
\text { KOLABORASI RESOLUSI KONFLIK }\end{array}$ & VOLUME 1 & NOMOR 1 & HALAMAN 1-70 & $\begin{array}{c}\text { ISSN 2655-8823 }(p) \\
\text { ISSN - }(e)\end{array}$ \\
\hline
\end{tabular}

Berkaitan dengan konflik agraria Desa Genteng dalam sistem mikro, secara individu para petani memiliki masalah terkait dengan tidak dimilikinya lahan pertanian pribadi (tanah milik). Adanya masalah ini kemudian melahirkan kebutuhan akan lahan pertanian yang akan digunakan oleh mereka untuk bercocok tanam. Sebagai upaya pemenuhan kebutuhan tersebut, kekuatan (power) individu mendorong mereka untuk memanfaatkan tanah kehutanan terlantar miliki Perum Perhutani yang ada disekitar kawasan tempat tinggal mereka untuk melakukan aktivitas pertanian.

Berdasarkan sistem mezzo dapat dipahami bahwa masalah yang terjadi pada petani di Desa Genteng tersebut tidak hanya dialami oleh satu individu saja. Namun lebih luas lagi masalah ini dialami oleh hampir sebagian besar petani di Desa tersebut. Dalam sistem makro, upaya pemecahan masalah dengan memanfaatkan tanah kehutanan terlantar miliki Perum Perhutani ternyata menimbulkan masalah baru bagi masyarakat petani Desa Genteng yaitu ketika Perum Perhutani ingin mengambil alih lahan tersebut. Perbedaan kepentingan yang terjadi kemudian menimbulkan konflik agraria antara dua pihak tersebut. Hal inilah yang menurut Zastrow (2007) disebut sebagai kebijakan yang mempengaruhi akses masyarakat terhadap sumber daya. Uraian ini pada dasarnya telah mendukung pernyataan Zastrow yang menyebutkan bahwa setiap tingkah laku individu, kelompok dan masyarakat akan selalu dipengaruhi oleh lingkungan sosial mereka.

Konflik agraria yang terjadi di Desa Genteng ini pada dasarnya merupakan masalah yang terjadi pada level komunitas (sistem makro). Zastrow (2007:29) menyatakan bahwa sistem makro dalam sebuah masyarakat menjadi salah satu hal yang signifikan dalam memahami perilaku manusia. Salah satu teori yang dapat digunakan dalam memahami perilaku komunitas ini yaitu Teori Ekologi Manusia. Teori ekologi manusia menurut Fellin
(2001:119) yaitu teori yang berfokus pada hubungan atau interaksi komunitas dengan lingkungan mereka. Bagian dari interaksi ini melibatkan akses individu/komunitas pada sumber daya. Menurut pandangan Zastrow (2007) disetiap komunitas mana pun, beberapa kelompok pasti akan memiliki akses yang lebih besar pada sumber daya daripada yang lain. Menurut Fellin (2001:119) yang berlaku untuk sistem makro masyarakat meliputi competition, segregation dan integration. Competition, menyangkut bagaimana anggota masyarakat bersaing untuk memanfaatkan sumber daya. Sementara segregation adalah isolasi atau pembatasan beberapa kelompok terhadap akses menuju sumber daya tersebut. Sedangkan integration, mengacu pada proses menyatukan dan memadukan berbagai kelompok menjadi satu kesatuan yang utuh dan fungsional.

Berkaitan dengan penjelasan mengenai teori ekologi manusia tersebut, dapat dipahami bahwa competition dalam konflik agraria yang terjadi di Desa Genteng terjadi karena adanya perbedaan kepentingan dalam hal pemanfaatan sumber daya, persaingan antara dua pihak dalam pemanfaatan sumber daya dan adanya keterbatasan akses beberapa pihak terhadap sumber daya tersebut. Disatu sisi petani berusaha untuk memanfaatkan tanah terlantar milik Perum Perhutani yang ada di kawasan hutan di sekitar tempat tinggal mereka untuk bercocok tanam. Namun disisi lain, pemerintah mengeluarkan sebuah kebijakan melalui Perum Perhutani untuk melakukan konservasi hutan sebagai upaya untuk menjaga ekosistem dan kelestarian hutan. Hal ini mendukung pernyataan Firmansyah dkk (2018:63) yang menyebutkan bahwa konflik agraria merupakan sebuah konsekuensi yang harus dihadapi sebagai bagian atau cara dari pengaruh kebijakan yang diberlakukan pemerintah. Dari perbedaan kepentingan antar masyarakat lokal dengan Perum Perhutani tersebut, maka terjadilah persaingan (competition) antara kedua 


\begin{tabular}{|c|c|c|c|c|}
\hline $\begin{array}{c}\text { JURNAL } \\
\text { KOLABORASI RESOLUSI KONFLIK }\end{array}$ & VOLUME 1 & NOMOR 1 & HALAMAN 1-70 & $\begin{array}{c}\text { ISSN 2655-8823 }(p) \\
\text { ISSN - }(e)\end{array}$ \\
\hline
\end{tabular}

pihak dalam hal pemanfaatan lahan. Dalam persaingan tersebut, terjadi segregation yaitu dengan adanya pembatasan akses para petani untuk melakukan aktivitas pertanian di lahan kehutanan oleh Perum Perhutani.

Adanya konflik agraria di Desa Genteng, mendorong berbagai pihak terutama masyarakat lokal berusaha untuk melakukan resolusi konflik. Sebagai hasil dari resolusi konflik tersebut, maka diperolehlah integrasi sosial (integration). Integrasi disini menurut Fellin (2001), mengacu pada proses menyatukan dan memadukan berbagai kelompok yang berkonflik menjadi satu kesatuan yang utuh dan fungsional. Integrasi sebagai bagian resolusi konflik dalam konflik agraria ini yaitu Perum Perhutani memperbolehkan petani untuk melakukan aktivitas pertanian di lahan kehutanan dengan jenis tanaman yang telah ditentukan. Jenis tanaman ini yaitu tanaman kopi. Ketinggian lahan di Desa Genteng yang mencapai 1.200-1.500 mdpl sangat cocok untuk dijadikan tempat budidaya kopi. Upaya ini juga didukung secara langsung oleh Pemerintah Provinsi Jawa Barat melalui Program Penanaman Kopi Java Preanger. Hasil dari resolusi konflik ini tetap menjami para petani untuk dapat melakukan aktivitas di kawasan hutan, bahkan cara ini juga dapat meningkatkan kesejahteraan para petani. Hal ini karena tanaman kopi memiliki nilai ekonomi yang tinggi dan tidak kalah dengan jenis tanaman lainnya.

Menurut Ralf Dahrendrof dalam Bakri (2015) resolusi konflik yang efektif sangat bergantung pada tiga faktor. Pertama, kedua pihak harus mengakui kenyataan dan situasi konflik diantara mereka. Kedua, kepentingan yang diperjuangkan harus terorganisir sehingga masing-masing pihak memahami tuntutan pihak lain. Ketiga, kedua pihak menyepakati aturan main yang menjadi landasan dalam hubungan interaksi diantara mereka.

Berdasarkan hal tersebut, tujuan dilakukannya upaya resolusi konflik ini pada dasarnya yaitu untuk menghentikan konflik antara masyarakat lokal dengan
Perum Perhutani agar tidak terus berlanjut. Ketika konflik terjadi kedua aktivitas dari kedua pihak yang terlibat konflik ini tidak dapat dilaksanakan secara optimal. Masyarakat lokal tidak dapat melakukan aktivitas pertaniannya yang berdampak pada hilangnya sumber mata pencaharian dan pendapatan mereka. Perum Perhutani juga tidak dapat melakukan aktivitasnya di kawasan hutan yang menjadi wilayah konflik karena dihalang-halangi oleh masyarakat lokal. Dengan dilakukannya resolusi konflik, aktivitas kedua pihak tersebut dapat dilaksanakan tanpa ada kekhawatiran satu sama lain.

Kedua, resolusi konflik yang dilakukan juga bertujuan untuk memperjuangkan dan mengoranisir kepentingan kedua belah pihak. Dengan adanya integrase sosial yang telah dijelasakan dimuka, maka petani Desa Genteng dapat melakukan aktivitas pertanian di kawasan hutan sebagai salah satu sumber mata pencaharian serta pendapatan mereka, disisi lain tujuan Perum Perhutani untuk melakukan konservasi hutan pun dapat terpenuhi. Terakhir, tujuan dari resolusi konflik agraria Desa Genteng ini yaitu agar kedua belah pihak yang berkonflik saling menyepakati aturan yang telah dibuat.

Selain menggunakan Teori Ekologi Manusia, konfik agraria di Desa Genteng ini dapat juga dilihat dengan menggunakan perspektif Teori Konflik. Zastrow (2007:442) menyebutkan bahwa pada dasarnya konflik merupakan upaya memperjuangkan kekuasaan diantara berbagai kelompok sosial. Sementara itu, Oko (2008:22) berpendapat bahwa berdasarkan teori konflik, masyarakat terbentuk karena adanya ketidaksamaan, ketidakadilan dan ketidaksetaraan, konflik sosial yang terjadi di masyarakat pada dasarnya merupakan respon yang tidak terhindarkan dari adanya ketidaksetaraan tersebut. Sejalan dengan hal tersebut, Fisher (2002) juga mengemukakan pendapat yang sama yaitu bahwa konflik terjadi karena adanya kebutuhan manusia baik secara fisik, mental maupun sosial 


\begin{tabular}{|c|c|c|c|c|}
\hline $\begin{array}{c}\text { JURNAL } \\
\text { KOLABORASI RESOLUSI KONFLIK }\end{array}$ & VOLUME 1 & NOMOR 1 & HALAMAN 1-70 & $\begin{array}{c}\text { ISSN 2655-8823 }(p) \\
\text { ISSN - }(e)\end{array}$ \\
\hline
\end{tabular}

yang tidak terpenuhi atau terhalangi. Berdasarkan asumsi teori konflik tersebut, kasus konflik agraria di Desa Genteng muncul ketika adanya keterbatasan sumber daya yang dibutuhkan oleh manusia yang dalam hal ini yaitu lahan pertanian. Keterbatasan sumber daya ini menyebabkan konflik pada masyarakat karena orang-orang baik secara individu maupaun kelompok berusaha untuk saling menguasai sumber daya tersebut.

Konflik sering kali dianggap sebagai sesuatu hal yang negatif. Namun menurut para pendukung teori konflik, pada dasarnya konflik juga sangat bermanfaat bagi masyarakat. Hal ini dapat dilihat dari hasil konflik itu sendiri yang sering kali melahirkan konsensus baru dan perubahan sosial positif di masyarakat. Konflik dapat melahirkan penataan ulang distribusi sumber daya yang langka di antara kelompok-kelompok masyarakat yang berkonflik. Konflik dapat mengarah pada perbaikan, kemajuan, pengurangan diskriminasi terhadap kelompok yang tertindas, dan munculnya kelompokkelompok baru sebagai kekuatan dominan di masyarakat. Tanpa konflik, masyarakat akan menjadi stagnan. Dalam hal ini, konflik agraria yang terjadi di Desa Genteng telah melahirkan konsensus baru di masyarakat yaitu dengan diperbolehkannya para petani untuk melakukan aktivitas pertanian di lahan kehutanan melalui Program Penanaman Kopi Java Preanger.

\section{KESIMPULAN}

Berdasarkan uraian dimuka, maka dapat disimpulkan beberapa hal dari konflik agraria di Desa Genteng ini, yaitu:

a. Konflik agraria Desa Genteng terjadi karena adanya perbedaan kepentingan dalam hal pemanfaatan lahan kehutanan antara masyarakat lokal dengan Perum Perhutani. Selain itu, konflik ini juga terjadi karena adanya ketidaksamaan, ketidakadilan dan ketidaksetaraan, konflik sosial yang terjadi di masyarakat pada dasarnya merupakan respon yang tidak terhindarkan dari adanya ketidaksetaraan tersebut.

b. Konflik agraria yang terjadi di Desa Genteng terjadi pada multiple system mulai dari sistem mikro, mezzo maupun makro.

c. Pada konflik agraria di Desa Genteng terdapat competition, segregation dan integration. Competition yaitu karena adanya perbedaan kepentingan dalam hal pemanfaatan sumber daya, persaingan antara dua pihak dalam pemanfaatan sumber daya dan adanya keterbatasan akses beberapa pihak terhadap sumber daya tersebut. Segregation yaitu adanya pembatasan akses para petani untuk melakukan aktivitas pertanian di lahan kehutanan oleh Perum Perhutani. Sedangkan sebagai hasil dari resolusi konflik diperolehlah integrasi sosial (integration) yaitu Perum Perhutani memperbolehkan petani untuk melakukan aktivitas pertanian di lahan kehutanan dengan jenis tanaman yang telah ditentukan. Integrasi sosial ini juga dapat dianggap sebagai konsensus baru dan perubahan sosial positif di masyarakat.

d. Tujuan dilakukannya upaya resolusi konflik ini pada dasarnya yaitu untuk menghentikan konflik, memperjuangkan dan mengoranisir kepentingan kedua belah pihak dan agar kedua belah pihak yang berkonflik saling menyepakati aturan yang telah dibuat.

\section{UCAPAN TERIMA KASIH}

Ucapan terima kasih disampaikan kepada editor dan mitra bestari, yang telah memberikan masukan-masukan demi kesempurnaan artikel ini. Juga kepada pengelola Jurnal Kolaborasi Resolusi Konflik, yang telah memberikan kesempatan untuk menerbitkan artikel 


\begin{tabular}{|c|c|c|c|c|}
\hline $\begin{array}{c}\text { JURNAL } \\
\text { KOLABORASI RESOLUSI KONFLIK }\end{array}$ & VOLUME 1 & NOMOR 1 & HALAMAN 1-70 & $\begin{array}{c}\text { ISSN 2655-8823 }(p) \\
\text { ISSN - }(e)\end{array}$ \\
\hline
\end{tabular}

kami. Kemudian, terima kasih juga disampaikan kepada dosen pengampu mata kuliah Teori Intervensi Individu dan Keluarga serta mata kuliah Tingkah Laku Manusia dengan Lingkungan Program Pascasarjana Kesejahteraan Sosial FISIP UNPAD yang telah menyediakan waktu untuk berdisikusi dalam mendalami analisis yang ditulis ke dalam artikel ini.

\section{DAFTAR PUSTAKA \\ Buku dan Jurnal}

Bakri, Hendry. (2015). Resolusi Konflik melalui Pendekatan Kearifan Lokal Pela Gandong di Kota Ambon. The POLITICS: Jurnal Magister Ilmu Politik Universitas Hasanuddin Volume 1, Number 1, January 2015.

Chandra, Robby. (1992). Konflik Dalam Kehidupan Sehari-Hari. Yogyakarta: Kanisius.

Fellin, P. (2001). Understanding American communities. In J. Rothman, J. L. Erlich, \& J. E. Tropman (Eds.), Strategies of community intervention (6thed., pp. 118 -132). Itasca, IL: Peacock. Felsman, D.

Firmansyah, Anry; Raharjo, Santoso Tri, Sintianingrum. (2018). Advocacy Coalition Framework dalam Penyelesaian Konflik Tanah di Badega Kabupaten Garut. Bandung: ITB Press.

Fisher Simon, Ibrahim, Dekka. (2002). Working With Conflict: Skill \& Strategies for Action. New York : Responding To Conflict.

Fisher, Simon, dkk. (2001). Mengelola Konflik: Keterampilan \& Strategi Untuk Bertindak. Jakarta: The British Council.

Fuad, H.F. \& Maskanah, S. (2000). Inovasi Penyelesaian Sengketa Pengelolaan Sumber Daya Hutan. Bogor: Pustaka Latin.

George Ritzer, Douglas J. Goodman. (2010). Teori Sosiologi Modern. Jakarta: Kencana.

Haider, Huma. (2009). Community-based Approaches to Peacebuilding in Conflict-affected and Fragile Contexts.
Governance and Social Development

Resource Center. University of Birmingham.

Harun, Marinus Kristiadi; Dwiprabowo, Hariyatno. (2014). Model Resolusi Konflik Lahan Di Kesatuan Pemangkuan Hutan Produksi Model Banjar. Jurnal Penelitian Sosial dan Ekonomi Kehutanan Vol. 11 No. 4 Desember 2014, Hal. 265 - 280.

Juliette Oko. (2007). Understanding and Using Theory in Social Work. Southernhay East: Learning Matters Ltd.

Konsorsium Pembaruan Agraria. (2017). Catatan Akhir Tahun 2017 Konsorsium Pembaruan Agraria: Reforma Agraria di Bawah Bayangan Investasi-Gaung Besar di Pinggiran Jalan. Jakarta: KPA.

Morton \& Coleman. (2000). The Handbook of Conflict Resolution. Illinois: Waveland Press Inc.

Nulhaqim, Soni Akhmad., Irfan, Maulana., Harding, Diana., Jatnika, Dyana Chusnulita. (2017). Konflik Sosial Di Kampung Nelayan : Studi Kasus di Pantai Utara Kota Cirebon, Jawa Barat. Jurnal Sosiokonsepsia Kementerian Sosial Republik Indonesia Volume 6 Nomor 2 Januari-April 2017.

Permadi, Iwan. (2016). Perlindungan Hukum Terhadap Petani Penggarap Tanah Negara Milik Perum Perhutani. Jurnal Arena Hukum Volume 9 Nomor 2 Agustus 2016, Halaman 225-252.

Putra, Bagus Ani. (2013). Peran kearifan lokal dalam resolusi konflik keyakinan beragama di Jawa Timur. Jurnal Masyarakat, Kebudayaan dan Politik Volume 26 Nomor 1 Tahun 2013, Halaman 1-14.

Putra, Said Hidayat, Turrintoro, Astuti, Puji. (2014). Faktor Determinan Konflik Agraria Di Desa Setrojenar Kecamatan Bulus pesantren Kabupaten Kebumen. Jurnal Ilmu Pemerintahan, Volume 1, No. 1, Tahun 2014.

Rokhmad, Abu. (2016). Paradigma Hukum Islam dalam Penyelesaian Sengketa. 


\begin{tabular}{|c|c|c|c|c|}
\hline $\begin{array}{c}\text { JURNAL } \\
\text { KOLABORASI RESOLUSI KONFLIK }\end{array}$ & VOLUME 1 & NOMOR 1 & HALAMAN 1-70 & $\begin{array}{c}\text { ISSN 2655-8823 }(p) \\
\text { ISSN - }(e)\end{array}$ \\
\hline
\end{tabular}

International Journal Ihya Ulum AlDin. Volume 18 Nomor 1 Tahun 2016. Wallensteen, Peter. (2002). Understanding Conflict Resolution: War, Peace and the Global System. London: SAGE Publications.

Zakie, Mukmin. (2016). Konflik Agraria yang Tak Pernah Reda. Jurnal Legality Volume 24 Nomor 1 Maret-Agustus 2016.

Zastrow, Charles \& Ashman, Karen K. Kirst. (2007). Understanding Human Behavior and the Social Environment. Thompson : Belmont, USA.

\section{Sumber Lain}

Undang-Undang Republik Indonesia Nomor 41 Tahun 1999 tentang Kehutanan.

Undang-Undang Republik Indonesia Nomor 5 Tahun 1960 tentang PokokPokok Agraria.

Undang-Undang Republik Indonesia Nomor 7 Tahun 2012 tentang Penanganan Konflik Sosial. 